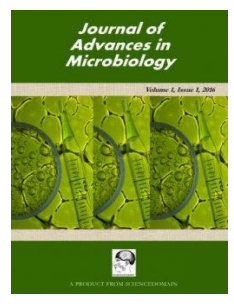

\title{
Lactic Acid Bacteria Profile of Fermenting Cucumber in $7 \%$ Brine Solution
}

\author{
J. G. Egbe ${ }^{1^{*}}$, J. A. Lennox ${ }^{1}$, P. Rao, Anitha ${ }^{1}$ and G. E. Umoafia ${ }^{1}$ \\ ${ }^{1}$ Department of Microbiology, Faculty of Biological Sciences, University of Calabar, \\ Cross River State, Nigeria.
}

Authors' contributions

This work was carried out in collaboration between all authors. Authors JGE and JAL designed the study, performed the statistical analysis, wrote the protocol and wrote the first draft of the manuscript.

Authors PRA and JGE managed the analyses of the study. Author GEU managed the literature searches. All authors read and approved the final manuscript.

Article Information

DOI: $10.9734 / J A M B / 2017 / 33457$

Editor(s):

(1) Gyanendra Singh, Gene Therapy \& Louisiana Vaccine Center, School of Medicine, LSU Health Sciences Center, Louisiana,

USA.

(2) Arun Karnwal, Microbiology, School of Bioengineering \& Biosciences, Lovely Professional University, India.

Reviewers:

(1) Abdeslam A. Sehraou, Mohammed Premier University, Oujda, Morocco.

(2) Paul Yahaya Idakwo, University of Maiduguri, Nigeria.

(3) Jorge Alberto Reyes Esparza, Universidad Autonoma Del Estado de Morelos, Mexico. Complete Peer review History: http://www.sciencedomain.org/review-history/19148

Original Research Article

Received $16^{\text {th }}$ April 2017

Accepted $12^{\text {th }}$ May 2017

Published 20 $0^{\text {th }}$ May 2017

\begin{abstract}
Fermentation was used since ancient times as an easy method of vegetables' preservation, which also maintains and/or improves the nutritional and sensory properties of vegetables. The aim of this study was to isolate, characterized and identify the lactic acid bacteria (LAB) in spontaneous fermentation of Cucumber. Cucumber samples were purchased from a vegetable stand in Watt market, Cross River State, Nigeria. They were fermented spontaneously for 7 days in $7 \%$ brine solution and samples were taken at $24 \mathrm{~h}$ intervals for LAB analysis. Thirty bacterial strains were isolated from different phases of the fermentation of cucumber and were characterized by the API $50 \mathrm{CHL}$ System of identification. Three lactic acid bacteria species were identified and included Lactobacillus plantarum, Leuconostoc mesenteroides, and Lactobacillus pentosus. After $24 \mathrm{~h}$ fermentation, Leuconostoc mesenteroides was isolated as the dominant LAB specie of the fermentation period. This trend continued until the fourth day where Lactobacillus plantarum became the dominant LAB isolate in the fermenting cucumber. As the fermentation proceeded, Lactobacillus pentosus, was then involved. The results also revealed a decrease in the occurrence
\end{abstract}


of Leuconostoc mesenteroides as the fermentation period increases. The present research thus shows the presence of LAB at different phases of fermenting cucumber. Therefore, the above mentioned isolates could be used as starter cultures for the commercial fermentation of vegetables.

Keywords: Lactic acid bacteria; cucumber; fermentation; fermented vegetables; starter culture.

\section{INTRODUCTION}

Mankind has exploited lactic acid bacteria (LAB) for thousands of years for the production of fermented foods because of their ability to produce desirable changes in taste, flavor and texture [1]. Different antimicrobial molecules such as lactic acid, acetic acid, hydrogen peroxide and bacteriocins produced by these bacteria are widely known to inhibit foodborne pathogens and food spoilage micro-organism, thereby extending the shelf-life and enhancing the safety of the food products [1]. The LAB in the fermented foods not only contribute to the taste, aroma and texture but also lower the product's $\mathrm{pH}$, effectively promoting its quality and safety [2]. Lactic acid (LA) fermentation is considered as a simple and useful form of biotechnology to keep and/or enhance the safety, nutritional, sensory and shelf life properties of vegetables and fruits [3].

Cucumber is an important vegetable consumed in Nigeria. Distribution and succession of lactic acid bacteria in cucumber have attracted special attention [4,5]. Lactic acid bacteria are intrinsically present in vegetables, plants materials and dairy products among other foods. Consequently, LAB may be added to minimally processed vegetable product intended for consumption [6]. LAB is natural colonizer of fresh vegetables and has been previously described as good antagonist of several bacteria and fungi in different food products [7]. According to [8], $\mathrm{LAB}$ has the potential to inhibit the growth of pathogenic and spoilage bacteria and possibility exist for using them to improve the shelf life of different foods.

The microbiota responsible for the spontaneous fermentation of several raw vegetables and fruits deserves a large interest as tool to improve the microbial safety of fermented foods $[9,10]$. Biopreservation is mainly due to the synthesis of a wide variety of antagonistic primary and secondary metabolites including organic acids, carbon dioxide, ethanol, hydrogen peroxide and diacetyl, antifungal compounds (e.g., fatty acids, phenyllactic acid), bacteriocins and antibiotics (reutericyclin) [9]. Among these compounds, bacteriocins have attracted the interest due to their potential use as safe and natural food preservatives. Although nisin is the only purified bacteriocin used thus far in industrially processed foods, many bacteriocins produced by various lactic acid bacteria, may have potential applications in foods. Exploitation of bacteriocinogenic lactic acid bacteria on common spoilage and poisoning of raw vegetables and fruits was largely carried out. Several examples of bio-preservation of fresh cut salads and other vegetables (e.g., apples and lettuce) from common spoilage (yeasts and moulds) and poisoning (Listeria innocua, Listeria monocytogenes and Escherichia coli) microorganisms were reported [9].

Notwithstanding the reliable value of the spontaneous fermentation to stabilize and preserve raw vegetables and fruits (e.g., cucumbers, onions, eggplants, red-beets, capers, lychee, cocoa beans, and persimmon), a number of factors are in favour of the use of selected starters. The risk of fermentation failure, the inadequate inhibition of spoilage and pathogen microorganisms, and the undesirable and not predictable variations of the sensory, nutritional and rheology properties are some of these factors. Contrarily to other fermented foods (e.g., cheeses, sausages and leavened baked goods), the use of starter cultures in vegetable and fruit fermentation is increasing only recently $[11,12]$.

Lactic acid bacteria play important role in food, feed fermentation and preservation either as the natural microflora or as starter culture added under controlled condition. The preservative effect exerted by $L A B$ is mainly due to the production of organic acids (such as lactic acid) which lowered pHs [13,14]. Spontaneous fermentation typically results from the competitive activity of a variety of autochthonous and contaminating microorganisms, which may lead to a high risk for failure. Both from a hygiene and safety perspective, the use of starter cultures is recommended, as it leads to rapid inhibition of spoilage and pathogenic bacteria while yielding processed fruit with consistent sensory and nutritional quality. Starter cultures with desirable properties and high counts of bacteria are of particular importance for the production of high quality fermented vegetable products. However, 
it is important to know that, there is few or lack of commercial bacterial cultures suitable for fermentation of vegetable. In view of that, there is need to deepen the search for more potent strain of LAB that can be employed as suitable starter cultures for the fermentation of vegetables. Therefore, this research work isolated, characterized and identified the various LAB involved in the spontaneous fermentation of cucumber.

\section{MATERIALS AND METHODS}

\subsection{Sample Collection and Processing}

Fresh cucumber samples were obtained from a vegetable stand in Watt Market, Calabar, Cross River State, Nigeria. They were fermented spontaneously at $37^{\circ} \mathrm{C}$ for 7 days in $7 \%$ brine solution and samples were taken at $24 \mathrm{~h}$ interval for microbial analysis.

\subsection{Isolation of Lactic Acid Bacteria}

After $24 \mathrm{~h}$ of fermentation, $0.1 \mathrm{ml}$ of $10^{-6}$ dilution of the sample was then spread plated on de Man Rogosa and Sharpe (MRS) agar and incubated at $37^{\circ} \mathrm{C}$ for $24-48 \mathrm{hrs}$. Colonies were randomly selected based on their morphological appearance and streak plating was then used to purify the isolates. The same procedure was repeated after every $24 \mathrm{hrs}$ for 7 days. The individual bacterial colonies were stored in MRS agar slant at $4^{\circ} \mathrm{C}$ for further analysis.

\subsection{Identification of Lactic Acid Bacterial Isolates}

Isolates were identified using API $50 \mathrm{CHL}$ system (bioMerieux). For primary species- specific identification, bacterial strain were subjected to API $50 \mathrm{CHL}$ assay. Purified strains were cultured on MRS plates, after which grown colonies were cultivated in $5 \mathrm{ml}$ of MRS both at $30^{\circ} \mathrm{C}$. The result was read after $24 \mathrm{~h}$ and verified after $48 \mathrm{~h}$. Fermentation of carbohydrates in the carbohydrate medium was indicated by a yellow colour, except for esculine (dark brown). Color reactions were scored against a chart provided by the manufacturer. The isolates were also Gram stained to determine their gram's reaction as well as cell morphology and arrangements.

\section{RESULTS}

Thirty bacterial strains were isolated from different phases of the fermentation of cucumber and were characterized by the API $50 \mathrm{CHL}$ System of identification. The cultural characteristics of the isolates are shown in Table 1. All the thirty isolates reacted positively to gram staining. Morphologically, the cells of 10 isolates were coccus type and arranged either in pairs or tetrads. Their colonies on MRS agar were circular, low convex with entire margin and cream colored. The cells of the remaining 20 were rod shaped and arranged in pairs or chains. Fifteen of the isolates were identified as Lactobacillus plantarum, ten as Leuconostoc mesenteroides, three as Lactobacillus pentosus and two isolates were characterized as Lactobacillus sp as they could not been able to be identified at species level. This result is presented in Table 2. After $24 \mathrm{~h}$ fermentation Leuconostoc mesenteroides was found to be the most dominant lactic acid bacteria isolated, followed by Lactobacillus plantarum. This trend continued until the fourth day of fermentation where Lactobacillus plantarum became the dominant lactic acid bacteria in the fermenting cucumber. As the fermentation proceeded, Lactobacillus pentosus was then involved. This agrees with the work of [15]. They showed the different categories of lactic acid bacteria involved in the fermentation of cucumber based on their carbohydrate fermentation capabilities. The heterofermenters initiate the desirable lactic acid fermentation process. This was carried out by Leuconostoc mesenteroides as observed from the results. Leuconostoc mesenteroides initiates growth in vegetables more rapidly over a range of temperatures and salt concentrations than any other lactic acid bacteria. It produces carbon dioxide and acids which rapidly lower the $\mathrm{pH}$ and inhibit the development of undesirable microorganisms. Once the acidity increases to a specific level, Lactobacillus plantarum takes over the fermentation. It's a homofermenter which only produce lactic acid.

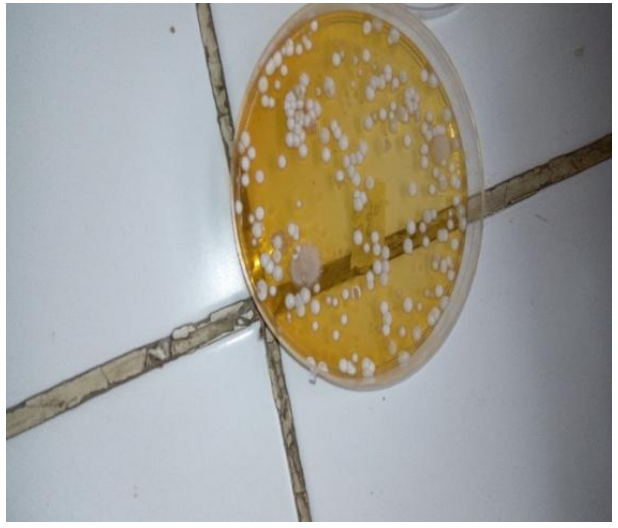

Plate A. Showing different colonies of LAB on MRS agar plate 


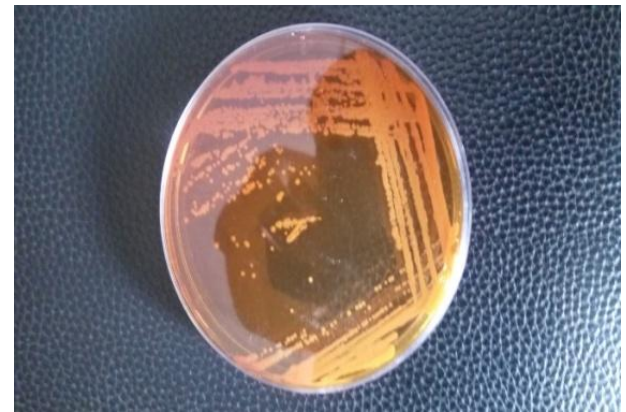

\section{Plate B. Showing discrete colonies of} subculture $L A B$ isolate

\section{DISCUSSION}

Traditionally fermented foods, including fermented vegetables can be a rich source of new LAB strains, with interesting functional properties and with potential applications in food industry and health [16]. Sauerkraut, fermented cucumbers, and kimchi are the most studied lactic acid fermented vegetables mainly due to their commercial importance. The use of starter cultures selected within the autochthonous microbiota of vegetables and fruit is increasing. Compared to commercial LAB, autochthonous strain show better performances during

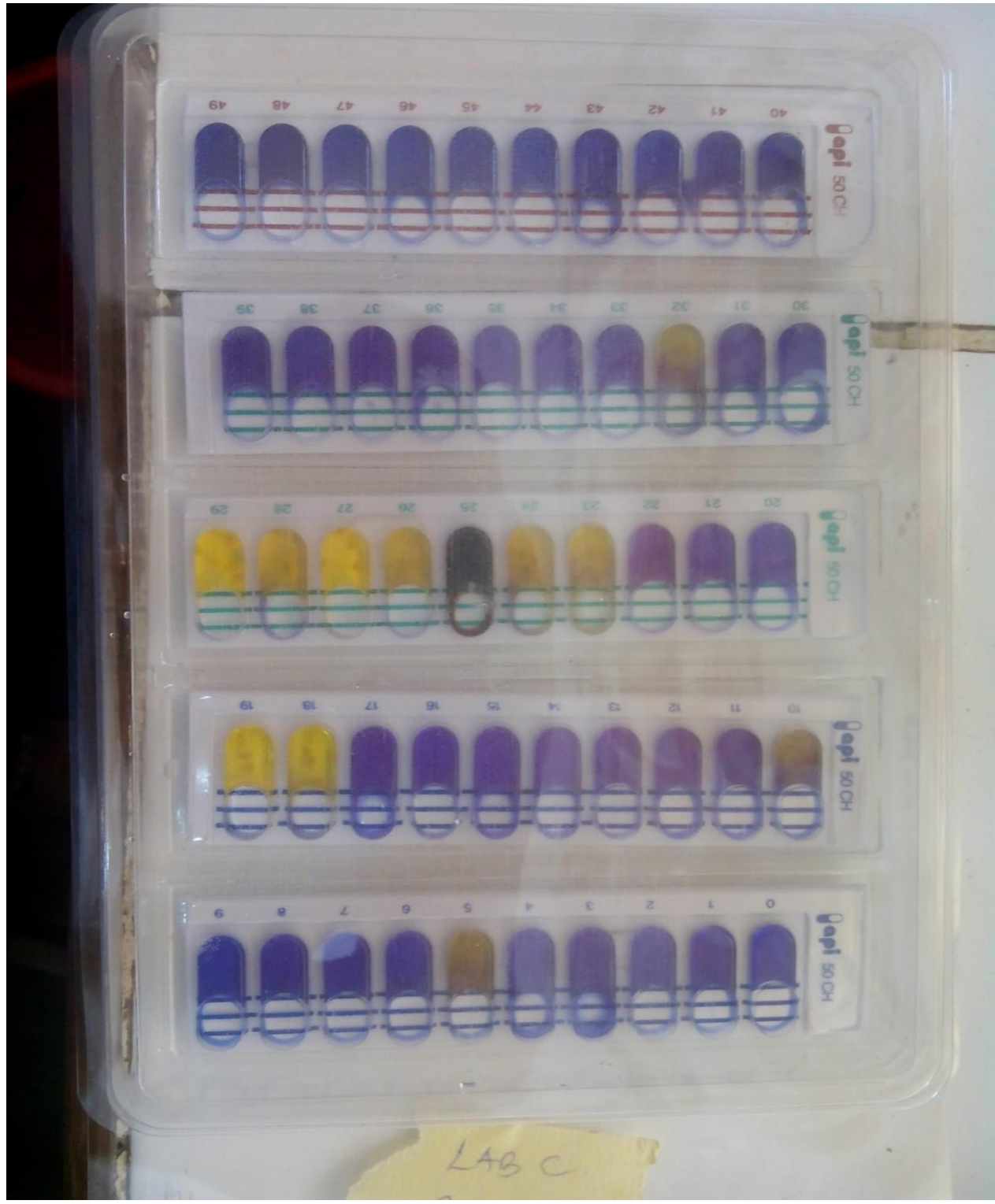

Plate C. API fermentation kit for LAB isolate C 
fermentation and especially ensure higher viability during storage [17]. Fermentation of fruits and vegetables can occur "spontaneously" by the natural lactic bacterial surface microflora, such as Lactobacillus spp, Leuconostoc spp, and Pediococcus spp.; however, the use of starter culture such as $L$. plantarum, $L$. rhamnosus, $L$. gasseri, and $L$. acidophilus provides consistency and reliability of performance [18]. The present research thus investigated the $L A B$ present at different phases of fermenting cucumber. The result of the study revealed that Lactobacillus plantarum, Leuconostoc mesenteroides and Lactobacillus pentosus were the main LAB involved in the spontaneous fermentation of cucumber. This is in line with the work of [15], were these $L A B$ species were involved in the microbial dynamics of fermenting cucumber. These species particularly Lactobacillus plantarum and Leuconostoc mesenteroides are typical for spontaneous fermentation of vegetables [19]. The result of this study is in accordance with those obtained by [20]. They isolated several lactobacillus strains from fermented vegetables, however, Lactobacillus plantarum was the dominating specie in natural cucumber fermentation. The result also revealed a decrease in the occurrence of Leuconostoc mesenteroides as the fermentation period increases. This could be as a result of acid formation (Lactic acid). This agreed with the work of [21], where they showed that $L$. plantarum was chiefly responsible for the brine acidity of the fermented cucumbers and that other common types of LAB such as species of Leuconostoc or the gas-producing species of Lactobacillus did not contribute to acid formation in the fermentation. Lactobacillus plantarum isolated in this work is in line with the work of [22], who isolated Lactobacillus plantarum from commercial cucumber fermentation. The ability of some species of LAB particularly Lactobacillus plantarum in acidification of the substrates is significant in food preservation [23]. Consumer

Table 1. Macro morphological characteristics of the isolates

\begin{tabular}{|c|c|c|c|c|c|}
\hline $\begin{array}{l}\text { Isolate-code/ } \\
\text { fermentation time }\end{array}$ & $\begin{array}{l}\text { Gram's } \\
\text { reaction }\end{array}$ & Pigmentation & Size & Elevation & $\begin{array}{l}\text { (Cell-shape) } \\
\text { morphology }\end{array}$ \\
\hline $\mathrm{LD}_{1-\mathrm{a}}$ & + & Creamy & Tiny & Raised & Cocci \\
\hline $\mathrm{LD}_{1-\mathrm{b}} \mathrm{b}$ & + & Creamy & Large & Raised & Cocci \\
\hline $\mathrm{LD}_{1-\mathrm{C}}$ & + & Creamy & Large & Raised & Rod \\
\hline $\mathrm{LD}_{2-} \mathrm{a}$ & + & White & Tiny & Flat & Cocci \\
\hline $\mathrm{LD}_{2-} \mathrm{b}$ & + & Creamy & Tiny & Flat & Rod \\
\hline $\mathrm{LD}_{2-\mathrm{C}} \mathrm{C}$ & + & Creamy & Large & Flat & Rod \\
\hline$L^{2-} d$ & + & White & Large & Flat & Cocci \\
\hline $\mathrm{LD}_{3-} \mathrm{a}$ & + & White & Large & Raised & Cocci \\
\hline $\mathrm{LD}_{3-} \mathrm{b}$ & + & White & Large & Flat & Cocci \\
\hline $\mathrm{LD}_{3-} \mathrm{C}$ & + & Creamy & Small & Raised & Rod \\
\hline $\mathrm{LD}_{3-} \mathrm{d}$ & + & White & Tiny & Raised & Rod \\
\hline $\mathrm{LD}_{3-} \mathrm{e}$ & + & Creamy & Tiny & Flat & Cocci \\
\hline$L_{3-} f$ & + & Creamy & Small & Pin point & Rod \\
\hline $\mathrm{LD}_{4-\mathrm{a}} \mathrm{a}$ & + & White & Tiny & Flat & Rod \\
\hline $\mathrm{LD}_{4-} \mathrm{b}$ & + & White & Tiny & Flat & Rod \\
\hline $\mathrm{LD}_{4-\mathrm{C}} \mathrm{C}$ & + & White & Small & Pin point & Rod \\
\hline $\mathrm{LD}_{4-\mathrm{d}} \mathrm{d}$ & + & White & Large & Raised & Rod \\
\hline $\mathrm{LD}_{4-\mathrm{e}} \mathrm{e}$ & + & Creamy & Large & Raised & Rod \\
\hline $\mathrm{LD}_{4-\mathrm{f}}$ & + & Creamy & Small & Flat & Rod \\
\hline$L^{2} D_{5} a$ & + & White & Large & Flat & Cocci \\
\hline $\mathrm{LD}_{5-} \mathrm{b}$ & + & White & Small & Raised & Rod \\
\hline $\mathrm{LD}_{5-} \mathrm{C}$ & + & Creamy & Small & Raised & Rod \\
\hline $\operatorname{LD}_{6-} \mathrm{a}$ & + & White & Large & Pin point & Rod \\
\hline$L_{6}-b$ & + & Creamy & Small & Flat & Rod \\
\hline $\mathrm{LD}_{6-\mathrm{C}} \mathrm{C}$ & + & White & Small & Flat & Rod \\
\hline $\mathrm{LD}_{6-} \mathrm{d}$ & + & Creamy & Large & Raised & Rod \\
\hline$L_{6-} \mathrm{e}$ & + & Creamy & Tiny & Flat & Rod \\
\hline LD7_a & + & Creamy & Large & Flat & Rod \\
\hline LD7_b & + & Creamy & Small & Raised & Rod \\
\hline LD7_c & + & creamy & Small & Raised & Rod \\
\hline
\end{tabular}


Table 2. Phenotypic identification of lactic acid bacteria from fermenting cucumber using API 50 CHL gallery kit

\begin{tabular}{|c|c|c|}
\hline Sample LAB & Identification & $\%$ of reliability of identification \\
\hline $\mathrm{LD}_{1-a} \mathrm{a}$ & Leuconostoc mesenteroides & $87.5 \%$ \\
\hline $\mathrm{LD}_{1-} \mathrm{b}$ & Leuconostoc mesenteroides & $98.9 \%$ \\
\hline $\mathrm{LD}_{1-\mathrm{C}} \mathrm{C}$ & Lactobacillus plantarum & $99.3 \%$ \\
\hline $\mathrm{LD}_{2-} \mathrm{a}$ & Leuconostoc mesenteroides & $98.1 \%$ \\
\hline $\mathrm{LD}_{2-} \mathrm{b}$ & Lactobacillus plantarum & $73.8 \%$ \\
\hline $\mathrm{LD}_{2-} \mathrm{C}$ & Leuconostoc mesenteroides & $97.2 \%$ \\
\hline $\mathrm{LD}_{2-} \mathrm{d}$ & Leuconostoc mesenteroides & $90.3 \%$ \\
\hline $\mathrm{LD}_{3-} \mathrm{a}$ & Leuconostoc mesenteroides & $99.5 \%$ \\
\hline $\mathrm{LD}_{3-} \mathrm{b}$ & Leuconostoc mesenteroides & $98.8 \%$ \\
\hline $\mathrm{LD}_{3-} \mathrm{C}$ & Leuconostoc mesenteroides & $99.0 \%$ \\
\hline $\mathrm{LD}_{3-} \mathrm{d}$ & Lactobacillus pentosus & $67 \%$ \\
\hline$L^{2} D_{3} e$ & Lactobacillus plantarum & $99.1 \%$ \\
\hline$L_{3-} f$ & Leuconostoc mesenteroides & $64.5 \%$ \\
\hline $\mathrm{LD}_{4-} \mathrm{a}$ & Lactobacillus plantarum & $96.8 \%$ \\
\hline $\mathrm{LD}_{4-} \mathrm{b}$ & Lactobacillus pentosus & $99.2 \%$ \\
\hline $\mathrm{LD}_{4-} \mathrm{C}$ & Lactobacillus plantarum & $97.8 \%$ \\
\hline $\mathrm{LD}_{4-} \mathrm{d}$ & Lactobacillus petosus & $66.7 \%$ \\
\hline $\mathrm{LD}_{4-} \mathrm{e}$ & Leuconostoc mesenteroides & $98.3 \%$ \\
\hline $\mathrm{LD}_{4-} \mathrm{f}$ & Lactobacillus sp & $95.4 \%$ \\
\hline $\mathrm{LD}_{5-} \mathrm{a}$ & Lactobacillus plantarum & $71.4 \%$ \\
\hline $\mathrm{LD}_{5-} \mathrm{b}$ & Lactobacillus plantarum & $89.6 \%$ \\
\hline $\mathrm{LD}_{5-} \mathrm{C}$ & Lactobacillus plantarum & $90.5 \%$ \\
\hline $\mathrm{LD}_{6-} \mathrm{a}$ & Lactobacillus plantarum & $90.6 \%$ \\
\hline $\mathrm{LD}_{6-} \mathrm{b}$ & Lactobacillus plantarum & $98.4 \%$ \\
\hline $\mathrm{LD}_{6-} \mathrm{C}$ & Lactobacillus plantarum & $94.7 \%$ \\
\hline $\operatorname{LD}_{6-} d$ & Lactobacillus plantarum & $99.2 \%$ \\
\hline $\mathrm{LD}_{6-} \mathrm{e}$ & Lactobacillus plantarum & $96.8 \%$ \\
\hline LD7_a & Lactobacillus plantaum & $87.5 \%$ \\
\hline LD7_b & Leuconostoc mesenteroides & $96.8 \%$ \\
\hline LD7_c & Lactobacillus sp & $80.7 \%$ \\
\hline
\end{tabular}

interest for diverse fermented foods has increased in recent years because of the positive perception of their beneficial impact on health. Hence, there is an evident need to find novel methods and new food preservation agents from natural origins. Biopreservation refers to extending the shelf-life and enhancing the safety of foods using microorganisms or their metabolites [24]. In this aspect, LAB are very good candidates [25].

\section{CONCLUSION}

It can be seen that the Lactic acid bacteria involved in the spontaneous fermentation of cucumber are Lactobacillus plantarum, Leuconostoc mesenteroides and Lactobacillus pentosus. These lactic acid bacteria species can be exploited as starter cultures for the fermentation of other vegetables and fruits.

\section{COMPETING INTERESTS}

Authors have declared that no competing interests exist.

\section{REFERENCES}

1. Mahantesh MP, Ajayi P, Anand T, Ramana $\mathrm{KV}$. Isolation and characterization of lactic acid bacteria from curd and cucumber. Indian Journal of Biotechnology. 2009;9: 166-172.

2. Kopermsub P, Yunchalard S. Identification of lactic acid bacteria associated with the production of plaasom, a traditional fermented fish product of Thailand. International Journal of Food Microbiology. 2010;138:200-204.

3. Demir N, Bahceci KS, Acar J. The effects of different initial Lactobacillus plantarum 
concentrations on some properties of fermented carrot juice. Journal of Food Processing and Preservation. 2006;30:352-363.

4. Chen $Y$, Wua H, Chi-rong $Y$, Chena Z, Lua $Y$, Yanagidab $F$. Isolation and characterization of lactic acid bacteria from xi-gua-mian (fermented watermelon), a traditional fermented food in Taiwan. Journal of Science, Food and Agriculture. 2012;92:2069-2075.

5. Singh AK, Ramesh A. Succession of dominant and antagonistic lactic acid bacteria in fermented cucumber: Insights from a PCR-based approach. Journal of Food Microbiology. 2008;25:278-287.

6. Caplice E, Fitzgerald GF. Food fermentations: Role of microorganisms in food production and preservation. International Journal of Food Microbiology. 1999;50:131-149.

7. Stiles M, Holzafel W. Lactic acid bacteria of food and their current taxonomy. International Journal of Food Microbiology. 1997;36:1-29.

8. Ogunbanwo ST, Sanni AI, Onilude AA. Effect of bacterinogenic Lactobacillus species on the shelf life of fufu, a traditional fermented cassava product. World Journal of Microbiology and Biotechnology. 2004;20:57-63.

9. Fan L, Truelstrup Hansen L. Fermentation and biopreservation of plant based foods with lactic acid bacteria. In: Hui, Y.H. (Ed.). Handbook of plant based fermented food and beverage technology, second ed. CRC Press, Boca Raton, USA. 2012;3548.

10. Paramithiotis S, Doulgeraki AI, Tsilikidis I, Nychas GJE, Drosinos EH. Fate of Listeria monocytogenes and Salmonella typhimurium during spontaneous cauliflower fermentation. Food Control. 2012;27:178-183.

11. Vega Leal-Sánchez $M$, Ruiz-Barba JL, Sánchez AH, Rejano L, Jimenez-Diaz R, Garrido A. Fermentation profile and optimization of green olive fermentation using Lactobacillus plantarum LPCO10 as a starter culture. Food Microbiology. 2003;20:421-430.

12. Montet D, Loiseau G, Kakhia-Rozis N. Microbial technology of fermented vegetables. In: Ray RC, Ward OP (Eds.). Microbial Biotechnology in Horticulture.
Science Publishers, Inc., New Hampshire, USA. 2006;1:309-343.

13. Cintas LM, Casaus MP, Herranz C, Nes IF, Hemandez PF. Review: Bacteriocins of lactic acid bacteria. International Journal of Food Science and Technology. 2001;7: 281-305.

14. Hutkins RW. Microbiology and technology of fermented foods. Ames, IA. Blackwell Publishing. 2006;473.

15. Lennox JA, Efiuvwevwere BJO. Microbial dynamics during cucumber fermentation. Global Research Journal of Microbiology. 2013;3(2):13-17.

16. Fred B, McFeeters RF, Perez-Diaz I, Cherl-Ho L. Fermented vegetables. Food microbiology: Fundamentals and frontiers, 4th Ed. Edited by MP, Doyle and RL, Buchanan. ASM Press, Washington, D.C; 2013.

17. Di Cagno R, Surico RF, Paradiso A, De Angelis M, Salmon JC, Buchin S, De Gara L, Gobbetti M. Effect of autochthonous lactic acid bacteria starters on healthpromoting and sensory properties of tomato juice. International Journal of Food Microbiology. 2013;128:473-483.

18. Karovǐcov'a J, Drd'ak M, Greif G, Hybenov'a E. The choice of strains of Lactobacillus species for the lactic acid fermentation of vegetable juices. European Food Research and Technology. 1999; 1:53-56.

19. Tamminen M, Joutsjoki T, Sjöblom M, Joutsen M, Palva A, Ryha"nen EL, Joutsjoki V. Screening of lactic acid bacteria from fermented vegetables by carbohydrate profiling and PCR-ELISA. Letters in Applied Microbiology. 2004;39:439-444.

20. Silvia SG, Medana Z. Isolation and characterization of lactic acid bacteria from Romanian fermented vegetables. Romanian Biotechnology Letter. 2011;16.

21. Fleming $\mathrm{H}$, Mcfeeters RF. Use of microbial cultures: Vegetable products. Food Technology. 1981;35:84-87.

22. Lu Z, Breidt F, Fleminga HP, Altermann E, Klaenhammer TR. Isolation and characterization of a Lactobacillus plantarum bacteriophage AJL-1 from a cucumber fermentation. International Journal of Food Microbiology. 2003;84: 225-235. 
23. Ammo MS, Mayo B. Selection criteria for lactic acid bacteria to be used as functional starter cultures in sausage production (an update). Meat Science. 2007;76:138146.

24. Ross RP, Morgan S, Hill C. Preservation and fermentation: Past, present and future. International Journal of Food Microbiology. 2002;79:3-16.
25. El-Ghaish S, Ahmadova A, Hadji-Sfaxi I, El Mecherfi KE, Bazukyan I, Choiseta Y, Rabesona H, Sitohy M, Popov YG, Kuliev AA, Mozzig F, Chobert JM, Haertle T. Potential use of lactic acid bacteria for reduction of allergenicity and for longer conservation of fermented foods. Trends Food Sciences Technology. 2011;22:509516.

(c) 2017 Egbe et al.; This is an Open Access article distributed under the terms of the Creative Commons Attribution License (http://creativecommons.org/licenses/by/4.0), which permits unrestricted use, distribution, and reproduction in any medium, provided the original work is properly cited.

Peer-review history:

The peer review history for this paper can be accessed here:

http://sciencedomain.org/review-history/19148 